\title{
Pollen Atlas of the flora of Egypt 5. Species of Scrophulariaceae
}

\author{
Nahed El-Husseini \\ and
}

\section{Eman Shamso.}

\section{The Herbarium, Faculty of Science, Cairo University, Giza 12613, Egypt.}

El-Husseini, N. \& Shamso, E. 2002. The pollen atlas of the flora of Egypt. 5. Species of Scrophulariaceae. Taeckholmia 22(1): 65-76.

Light and scanning electron microscope study of the pollen grains of 47 species representing 16 genera of Scrophulariaceae in Egypt was carried out. Pollen grains vary from subspheroidal to prolate; trizonocolpate to trizonocolporate. Exine's sculpture is striate, colliculate, granulate, coarse reticulate or microreticulate. Seven pollen types are recognized and briefly described, a key distinguishing the different pollen types and the discussion of its systematic value are provided.

Key words: Flora of Egypt, pollen atlas, Scrophulariaceae.

\section{Introduction}

The Scrophulariaceae is a family of about 292 genera and nearly 3000 species of cosmopolitan distribution. It is represented in the flora of Egypt by 50 species belonging to 16 genera, 8 tribes and 3 sub-families (El-Hadidi et al., 1999).

Within the family, a wide range of pollen morphology exists and provides not only an additional parameter for generic delimitation but also reinforces the validity of many of the larger taxa.

Erdtman (1952), gave a concise account of the pollen morphology of some members of the family. Several authors studied and described the pollen of species of the family among whom to mention: Risch (1939), Ikuse (1956), Natarajan (1957), Verghese (1968), Olsson (1974), Elisens (1985c \& 1986), Bolliger \& Wick (1990) and Argu (1980, 1990 \& 1993).

\section{Material and Methods}

Pollen grains of 47 species representing 16 genera of Scrophulariaceae were the subject of the present investigation. Polleniferous materials were removed from herbarium specimens kept at Cairo University Herbarium as well as fresh materials collected by the writers. Samples of each species were collected from their natural habitats as shown in Table (1).

For size measurements, the pollen material was boiled for a few minutes in water, macerated in a few drops of an aqueous $10 \%$ solution of $\mathrm{KOH}$ on a clean slide; then stained with safranin (1\% safranin solution in $50 \%$ ethanol), and mounted in glycerin jelly. The pollen samples were examined by Leitz light microscope and measured with the aid of a callibirated occular micrometer. The measurements are the means of the dimensions of at least 50 welldeveloped pollen grains of five different specimens.

* Continued from Bull. Fac. Sci. Assiut University 31(2B): $43-53$ (2002)

Received 16 March, 2002. Revision accepted 1 June, 2002 
Table (1): Collection data of the investigated taxa of Scrophulariaceae.

\begin{tabular}{|c|c|}
\hline Species & Locality \\
\hline Verbascum sinaiticum Benth. & $\begin{array}{l}\text { Deir El-Arbain, 12.5.1956; Täckholm s.n. (CAI) - Near the } \\
\text { Monastery of St. Catherine, 10.5.1965; El-Hadidi s.n. (CAI). }\end{array}$ \\
\hline V. sinuatum $L$. & Abu Zaabal, 9.4.1954; Boulos s.n. (CAI). \\
\hline $\begin{array}{l}\text { V. eremobium Murb. var. subsinguliflorum } \\
\text { Murb. }\end{array}$ & North of Ousaim from Oaga, Sinai, 26.5.1998; E. shamso s.n. (CAI). \\
\hline V. fruticulosum Post & $\begin{array}{l}17 \mathrm{Km} \text { East of El-Arish on the road to Rafah, 18.4.1985; Gibali s.n. } \\
\text { (CAI) - North of Qusaim from Ooga, 26.5.1998; E.Shamso s.n. } \\
\text { (CAI). }\end{array}$ \\
\hline V. letourneuxii Asch. & $\begin{array}{l}\text { Sallum, } 5 \mathrm{Km} \text { from boundary of the town, 24.5.1963; Täckholm et al. } \\
\text { s.n. (CAI) - El-Garawla, } 25 \mathrm{Km} \text { East Mersa Matruh, 1.4.1972; } \\
\text { Täckholm et al. s.n. (CAI). }\end{array}$ \\
\hline V. schimperianum Boiss. & Wadi Isla, April 1940; Hassib s.n. (CAI). \\
\hline Celsia parviflora Decne. & $\begin{array}{l}\text { Stepway to Gebel Musa, 11.5.1956; Täckholm s.n. (CAI) - Wadi El- } \\
\text { Arbain, St. Catherine, Sinai, 18.5.1988; Kassas s.n. (CAI). }\end{array}$ \\
\hline Anticharis arabica Endl. & $\begin{array}{l}\text { Gebel Elba, Wadi Aideib, 20.1.1962; Täckholm et al. s.n. (CAI) - } \\
\text { Gebel Elba district, up stream part of Wadi Mawaw across Gebel } \\
\text { Asotriba, 28.1.1962; Täckholm et al. } 1039 \text { (CAI). }\end{array}$ \\
\hline A. glandulosa Asch. & $\begin{array}{l}\text { Gebel Hamra Dom, 6.3.1967; Osborm \& Helmy s.n. (CAI) - Gebel } \\
\text { Elba, 27.4.1932; drar s.n. (CAI). }\end{array}$ \\
\hline A. linearis (Benth.) Hochst. ex Asch. & $\begin{array}{l}\text { Gebel Hamata, Red Sea, 7.2.1961; Täckholm et al. } 326 \text { (CAI) - } \\
\text { Gebel Elba, Wadi Haiteen, 27.1.1961; Täckholm et al. } 757 \text { (CAI). }\end{array}$ \\
\hline Lindenbergia indica (L.) Vatke & $\begin{array}{l}\text { Wadi Abar, Gebel Ataqa, 26.4.1958; Täckholm et al. s.n. (CAI) - } \\
\text { Wadi Hangalia, Red Sea Coast, 4.3.1961; Täckholm et al. } 42 \text { (CAI). }\end{array}$ \\
\hline Bacopa monnieri (L.) Pennell & $\begin{array}{l}\text { San El-Hagar El-Gibliya, Sharkiya, 25.6.1983; A. Amer } 2509 \text { (CAI) - } \\
20 \text { Km North Tanta, 21.9.1993; E.Shamso s.n. (CAI). }\end{array}$ \\
\hline Peplidium humifusum Delile & $\begin{array}{l}\text { Idfina, South of Rosetta, um El-Helkan, 23.7.1925; Simpson } 3492 \\
\text { (CAIM). }\end{array}$ \\
\hline Limosella aquatica L. & Giza, Zawiyat ElAryan, 9.2.1923; Simpson 1793 (CAIM). \\
\hline Lindernia parviflora (Roxb.) Haines & $\begin{array}{l}\text { Nile shore near Gebel Silsila, Kom ombo, 11.2.1964; Täckholm et al. } \\
93 \text { (CAI). }\end{array}$ \\
\hline Jamesbrittenia dissecta (Delile) Kuntze & On the Nile Island near Khizan, 25.2.19; G. Runkewitz s.n. (CAI). \\
\hline Anarrhinum forskaohlii (J.E.Gmel) Cufod. & $\begin{array}{l}\text { Along the stepway on Gebel Musa, 22.4.1961; Täckholm et al. s.n. } \\
\text { (CAI) - Gebel El-Deir close to the Monastrey of St. Catherine, } \\
\text { 11.5.1956; Täckholm s.n. (CAI). }\end{array}$ \\
\hline Misopates orontium (L.) Raf. & $\begin{array}{l}\text { Vicinity of Mersa Matruh, 1.4.1972; Täckholm et al. s.n. (CAI) - } \\
\text { Sinnuris district, El Silien, 10.4.1983; M. Abd El-Ghani } 3535 \text { (CAI). }\end{array}$ \\
\hline Kickxia elatine (L.) Dumort. & $\begin{array}{l}\text { Dakhla Oasis, 11.2.1931; Hassib s.n. (CAI) - Hibis Temple, Kharga } \\
\text { Oasis, 7.2.1952; Täckholm } \alpha \text { Kassas s.n. (CAI). }\end{array}$ \\
\hline K. floribunda (Boiss.) Täckh. $\alpha$ Boulos & $\begin{array}{l}\text { Wadi El-Maghara, 23.4.1959; Boulos s.n. (CAI) - Wadi Aber, Gebel } \\
\text { Ataqa, South of Suez, 8.3.1954; Boulos s.n. (CAI). }\end{array}$ \\
\hline K. aegyptiaca (L.) Nábélek & $\begin{array}{l}74 \text { Km West of Mersa Matruh, 23.5.1963; Täckholm et al. s.n. (CAI) } \\
\text { - Wadi Araba, 28.4.1995; E.shamso s.n. (CAI). }\end{array}$ \\
\hline K. acerbiana (Boiss.) Täckh. $\alpha$ Boulos. & $\begin{array}{l}179 \text { Km E of Edfu, 10.2.1961; Täckholm et al. } 699 \text { (CAI) - Gebel } \\
\text { Hamata, Red Sea Coast, 7.2.1961; Täckholm et al. } 366 \text { (CAI). }\end{array}$ \\
\hline
\end{tabular}


Table (1): Continued

\begin{tabular}{|c|c|}
\hline Species & Locality \\
\hline K. nubica (skan) Dandy & $\begin{array}{l}\text { Wadi Digla, eastern desert, 25.3.1985; M. Shaded s.n. (CAI) - Gebel } \\
\text { Hamara Dom, 6.3.1967; Osborn } \alpha \text { Helmy s.n. (CAI). }\end{array}$ \\
\hline K. macilenta (Decne.) Danin & $\begin{array}{l}\text { Wadi Feiran, Sinai, 24.4.1961; Täckholm et al s.n. (CAI) - In the } \\
\text { Vicinity of St Catherine Monastery, Sinai, 10.4.1963; Boulos s.n. } \\
\text { (CAI). }\end{array}$ \\
\hline K. gracilis (Benth.) D.A. Sutton & $\begin{array}{l}\text { Gebel Elba district, Wadi Kansisrob, 3.2.1962; Täckholm et al. } 1307 \\
\text { (CAI). }\end{array}$ \\
\hline $\begin{array}{l}\text { K. pseudoscoparia V.W. Smith \& D.A. } \\
\text { Sutton }\end{array}$ & $\begin{array}{l}\text { Wadi Mera Kwan, 10.2.1962; Täckholm et al. } 2000 \text { (CAI) - At the } \\
\text { Northern end of Wadi Allaqi, 5.3.1963; Abdallah } 1339 \text { (CAIM). }\end{array}$ \\
\hline K. hastata (R. Br. ex Benth.) Dandy & Gebel Elba, G. Darwin, 4.3.1938; shabetai 25536 (CAIM). \\
\hline Linaria haelava (Forssk.) F. Dietr. & $\begin{array}{l}\text { El-Kharouba, El-Sheikh zowayed Village, 3.4.1988; Hosni et al s.n. } \\
\text { (CAI) - Mitla pass, 7.4.1990; El-Garf s.n. (CAI). }\end{array}$ \\
\hline L. joppensis Bornm. & Rafah, El-Malaha, 9.4.1956; Khattab 55 (CAI). \\
\hline L. albifrons (sm.) Spreng. & $\begin{array}{l}\text { El Amirya, 26.3.1954; Boulos s.n. (CAI) - El-Kharuba, El Sheikh } \\
\text { Zowayed, 3.4.1988; Hosni et al. s.n. (CAI). }\end{array}$ \\
\hline L. simplex Desf. & Wadi El Raha, 9.4.1967; Chrtek $\propto$ Kosinova s.n. (CAI). \\
\hline L. tenuis (Viv.) Spreng. & $\begin{array}{l}\text { El-Arish - Rafah road, at } 5 \text { Km before Rafah, 3.4.1988; Hosni et al. } \\
\text { s.n. (CAI) - Wadi El-Arish, 18.3.1955; Boulos s.n. (CAI). }\end{array}$ \\
\hline Scrophularia arguta Sol. & $\begin{array}{l}\text { Gebel Hamata, Red Sea Coast, 7.2.1961; Täckholm et al. } 442 \text { (CAI) } \\
\text { - Gebel Elba district, Wadi Kansis - rob, 3.2.1962; Täckholm et al. } \\
\text { s.n. (CAI). }\end{array}$ \\
\hline S. deserti Delile. & $\begin{array}{l}\text { El Qattamia, Suez road, 27.3.1989; El Garf s.n. (CAI) - Sinai, Wadi } \\
\text { zawaniig, 7.12.1989; Hobbs s.n. (CAI). }\end{array}$ \\
\hline S. sinaica Benth. & $\begin{array}{l}\text { Wadi Garawi, Helwan desert, 4.4.1960; Täckholm et al. s.n. (CAI) - } \\
\text { Wadi Rishrash, affluent to the Wadi, 23.3.1982; Hassan } 489 \text { (CAI). }\end{array}$ \\
\hline S.canina L. & 2 Km east of sallum, 25.5.1963; Täckholm et al. s.n. (CAI). \\
\hline S. libanotica & $\begin{array}{l}\text { Below the summit of Gebel Musa, Sinai, 22.4.1961; Täckholm et al. } \\
\text { s.n. (CAI) - Farsh Liifa (Gebel Abbas Pasha), Sinai, 7.12.1989; } \\
\text { Hobbs s.n. (CAI). }\end{array}$ \\
\hline Veronica anagalloides Guss. & $\begin{array}{l}\text { El-Mahmudia; Minyet El Said, 14.8.1970; Ibrahim et al. s.n. (CAI) - } \\
\text { Beheira provinces, Damanhur, 18.3.1988; A. Amer 16173 (CAI). }\end{array}$ \\
\hline $\begin{array}{l}\text { V. anagallis - aquatica L. var. nilotica } \mathrm{R} \text {. } \\
\text { Uechtr. }\end{array}$ & $\begin{array}{l}\text { Nile bank at the cataract hotel Aswan, 2.7.1967; El-Hadidi } \propto \\
\text { Ghabbour s.n. (CAI). }\end{array}$ \\
\hline V. scardica Griseb. & $\begin{array}{l}\text { Kafr Mahfus } \propto \text { Beni Othman, El Fayoum, 20.11.1968; El-Hadidi s.n. } \\
\text { (CAI) - Al Harra, Ain Glit, 13.4.1980; M. Abd El-Ghani } 2612 \text { (CAI). }\end{array}$ \\
\hline V. catenata Pennell. & $\begin{array}{l}\text { El-Gedia, Kafr El-Sheikh, 3.4.1993; E. Shamso s.n. (CAI) - Beheira } \\
\text { province, Kon Hamada, 15.4.1988; A. Amer } 6755 \text { (CAI). }\end{array}$ \\
\hline V. cymbalaria Bodard. & $\begin{array}{l}\text { Samouha cultivations behind Nuzha gardens, Alexandria, 23.3.1956; } \\
\text { Täckholm } \propto \text { El-Hadidi s.n. (CAI). }\end{array}$ \\
\hline V. persica Poir. & Beheira province, Mahmudiya, 17.3.1987; A. Amer 9501 (CAI). \\
\hline V. polita Fr. & Beheira province, El-Mahmudia, 25.4.1987; A. Amer 10227 (CAI). \\
\hline V. campylopoda Boiss. & $\begin{array}{l}\text { Deir El Rabba at the enterance of Wadi El Arbaain, 23/25.4.1961; } \\
\text { Täckholm et al. s.n. (CAI). }\end{array}$ \\
\hline Striga hermonthica (Delile) Benth. & Banha, Ballana, 2.1.1964; Boulos s.n. (CAI). \\
\hline S. asiatica (L.) Kuntze & Abu Zaabal, 14.8.1966; El-Hadidi $\propto$ Khattab s.n. (CAI). \\
\hline
\end{tabular}


Materials for examination with light microscopy (LM) were prepared using the acetolysis method described by Erdtman (1960).

Materials for SEM examination were mounted on stubs, coated with gold, examined and photographed by JEOL JSM - 5400 LV Scanning Electron Microscope at $15 \mathrm{KV}$ in the Central Unit of Electron Microscopy, Assuit University, Assuit, Egypt.

Pollen descriptions are based on both optical examinations. The terminology follows Erdtman (1952), Praglowski \& Punt (1973) and Praglowski \& Raj (1979). A key to the pollen types, a comprehensive description and a photomicrograph for each pollen type are provided.

\section{Results and Discussion}

Table (2) summarizes the main palynological features of the 47 species of Scrophulariaceae represented in the flora of Egypt.

The pollen grains varied from subspheroidal to prolate. The subspheroidal grains are either oblate-spheroidal (P/E ranges from $0.93-0.98)$ or prolate-spheroidal (P/E ranges from $1.00-1.14)$, subprolate pollen grains (P/E ranges from $1.15-1.28)$ and prolate grains (P/E ranges from 1.34-1.56).

The polar axis (P) of the species examined ranged from $12.6 \mu \mathrm{m}$ (Kickxia hastata) to 39. $\mu \mathrm{m}$ (Verbascum sinaiticum); equatorial diameter (E) ranged from $12.0 \mu \mathrm{m}$ (Linaria halaeva) and $36.0 \mu \mathrm{m}$ (Veronica persica). The largest pollen grains among the examined species are those of the genera: Bacopa, Verbascum and veronica (P, 24-42 $\mu \mathrm{m})$, and the smallest ones are those of the genera: Jamesbrittania, Anarrhinum, Linaria and Kickxia (P, 12-21 $\mu \mathrm{m})$.

Pollen grains of all species examined have trizonocolpate or trizonocolporate apertures that are equally spaced around the equator. Colpae are fusiform (Plate III) or narrowly oblong (Plate ID), apocolpate (Plate IIA) or syncolpate (Plate IA), with membrane either smooth or granulated (Veronica, Plate IIC). The pore in trizonocolporate grain is either lolongate (Plate IVD) or circular (Plate IA).

SEM investigations showed that the surface of the tectum is striate (Veronica, Plate IIC\&D), colliculate (Striga, Plates IIA\&B), granulate (Peplidium, Plate IIIA). It is coarse reticulate (Plates ID \& IVB) to micro-reticulate (Plate IVD).

Seven pollen types are recognized, which can be distinguished through the following key:

\section{Key to pollen types}

1.a. Pollen grains in tetrads

Anticharis type

b. Pollen grains in monads

2.a. Pollen grains with 3-4(-5) zonocolpate apertures ......................................... 3

b. Pollen grains with 3-zonocolproate apertures ....................................... 2

3.a. Pollen grains with 4(-5) colpate apertures, exine sculpture colliculate ...... Striga type

b. Pollen grains with 3- colpate apertures, exine sculpture reticulate, striate or granulate

4.a. Exine sculpture reticulate ............................................... Bacopa type

b. Exine sculpture striate or granulate ...................................................... 5

5.a. Mesocolpi striate with granules at colpus membrane ........................ Veronica type

b. Mesocolpi granulate and smooth at colpus membrane .................. Peplidium type 
6.a. Pollen grains have narrow oblong colpi with rounded ends

Kickxia type

b. Pollen grains have fusiform colpi with pointed ends, wide at equator.

Scrophularia type

\section{Anticharis type}

Pollen grains united in tetrahedral or in decussate tetrads, and rarely in dyads. Single grains 3syncolporate, prolate to subprolate, mean polar axis ranges from 18.3-27.6 $\mu \mathrm{m}$, equatorial diam. ranges from 12.6-24.0 $\mu \mathrm{m}$; colpi long, fusiform, tapering to the poles and the three colpi are joined through anastomosis. Membrane thin and smooth, pore slightly annulate and operculate, circular; exine sculpture is striate-regulate (Plate IA\&B).

Representative species: Anticharis linearis, A. glandulosa, and A. arabica.

\section{Striga type}

Pollen grains 4(-5) colpate, prolate-spheroidal to subprolate, mean polar axis ranges from 18.9-21.9 $\mu \mathrm{m}$, and mean equatorial diam. ranges from 18.0-18.6 $\mu \mathrm{m}$. Apocolpate, colpi long, narrow, oblong and \pm tapering at poles, membrane \pm thick, and stranded; exine sculpture colliculate (Plate IIA\&B).

Representative species: Striga hermonthica and S. asiatica.

\section{Bacopa type}

Pollen grains vary from subspheriodal, mean polar axis ranges from 24.3-37.2 $\mu \mathrm{m}$, equatorial diam. ranges from 20.7-33.0 $\mu \mathrm{m}$, and prolate p. $18.6 \mu \mathrm{m}$ and E. $13.8 \mu \mathrm{m}$, colpi long, narrow, \pm rounded at poles, membrane thin and smooth. Exine sculpture is coarse reticulate to microreticulate pattern (Plate ID).

Representative species: Bacopa monnieri, Limosella aquatica, Jamesbrittania dissecta and Verbascum fruticulosum.

\section{Veronica type}

Pollen mostly prolate-spheroidal, mean polar axis ranges from 29.1-37.8 $\mu \mathrm{m}$, and equatorial diam. ranges from $25.9-36.0 \mu \mathrm{m}$, rarely prolate or subprolate, colpi wide, with densely coarse granules at the membrane and margins. Exine sculpture is striate (Plate IIC\&D).

Representative species: Veronica anagalloides, $V$. anagallis-aquatica var.nilotica, $V$. scardica, $V$. catenata, $V$. cymbalaria, $V$. persica, V. polita and V. campylopoda.

\section{Peplidium type}

Pollen grains are prolate, mean polar axis is $23.4 \mu \mathrm{m}$ and equatorial diam. is $15.0 \mu \mathrm{m}$, colpi long, narrow, rounded at poles and slightly equatorially constricted, membrane thin and smooth. Exine sculpture is granulate (Plate IIIA).

Representative species: Peplidium humifusum. 
Table (2): Main pollen morphological features of the examined species of Scrophulariaceae represented in the flora of Egypt.

\begin{tabular}{|c|c|c|c|c|c|c|}
\hline 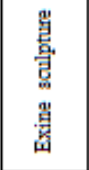 & 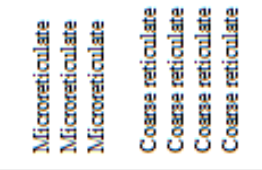 & 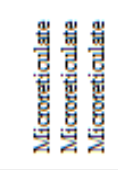 & 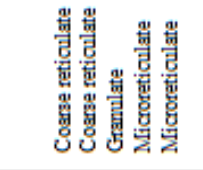 & 曾 & 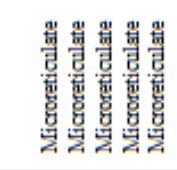 & 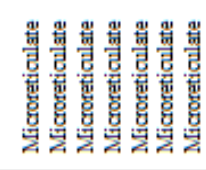 \\
\hline 总絮 & 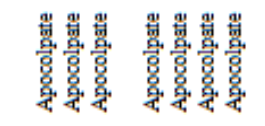 & 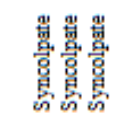 & 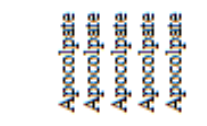 & & & \\
\hline 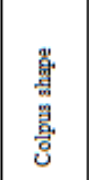 & 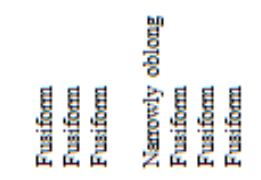 & 悬悬意 & 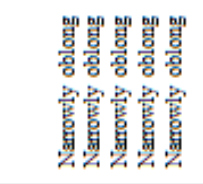 & 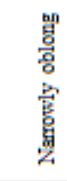 & 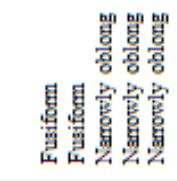 & 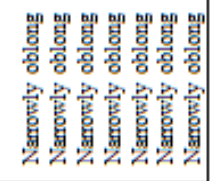 \\
\hline 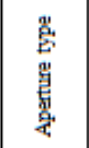 & 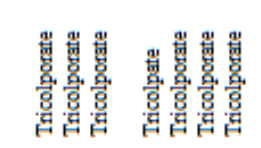 & 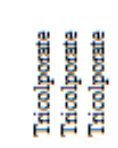 & 䯃: & 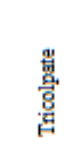 & & \\
\hline 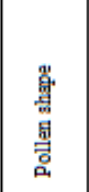 & 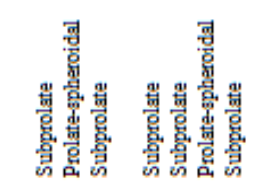 & 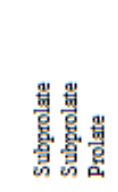 & 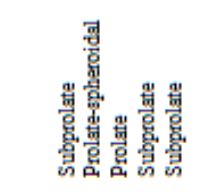 & 券 & 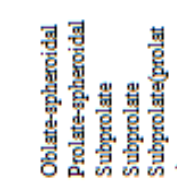 & 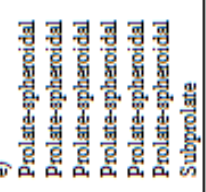 \\
\hline 䪪 & 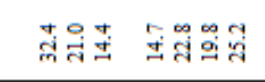 & 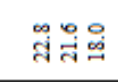 & 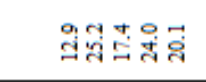 & $\stackrel{\circ}{~}$ & 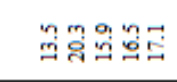 & a: \\
\hline 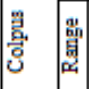 & 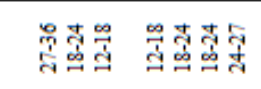 & 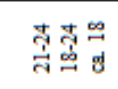 & 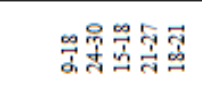 & 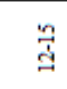 & 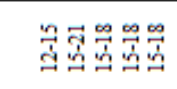 & \\
\hline 岕 & 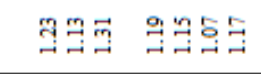 & 器骂骂 & 疋 & 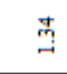 & 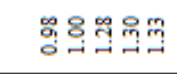 & \\
\hline 昜 & 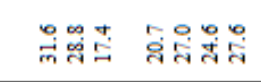 & 움울염 & 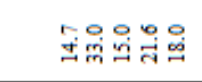 & $\stackrel{\substack{g\\
}}{2}$ & 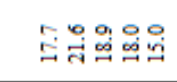 & \\
\hline 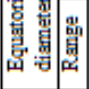 & 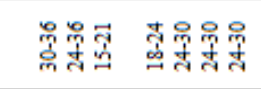 & 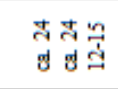 & 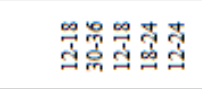 & 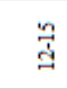 & 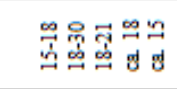 & \\
\hline \multirow{2}{*}{ 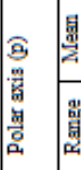 } & 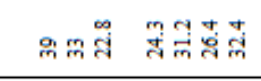 & 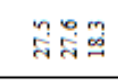 & 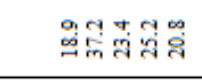 & $\stackrel{\circ}{\stackrel{\circ}{a}}$ & 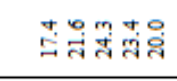 & \\
\hline & 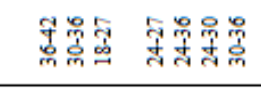 & 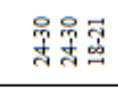 & 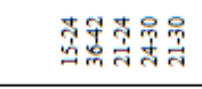 & בี & 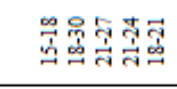 & 官苂 \\
\hline 量 & 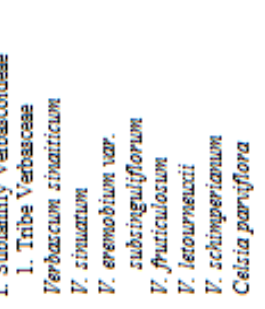 & 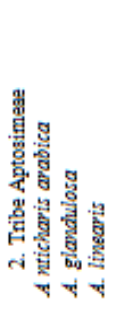 & 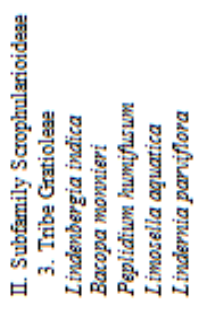 & 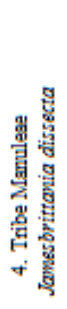 & 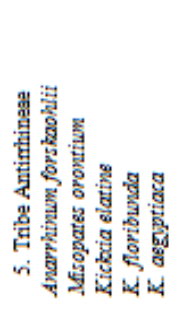 & 을 \\
\hline
\end{tabular}


Pollen Atlas of the flora of Egypt. 5. Species of Scrophulariaceae

Table (2): Continued.

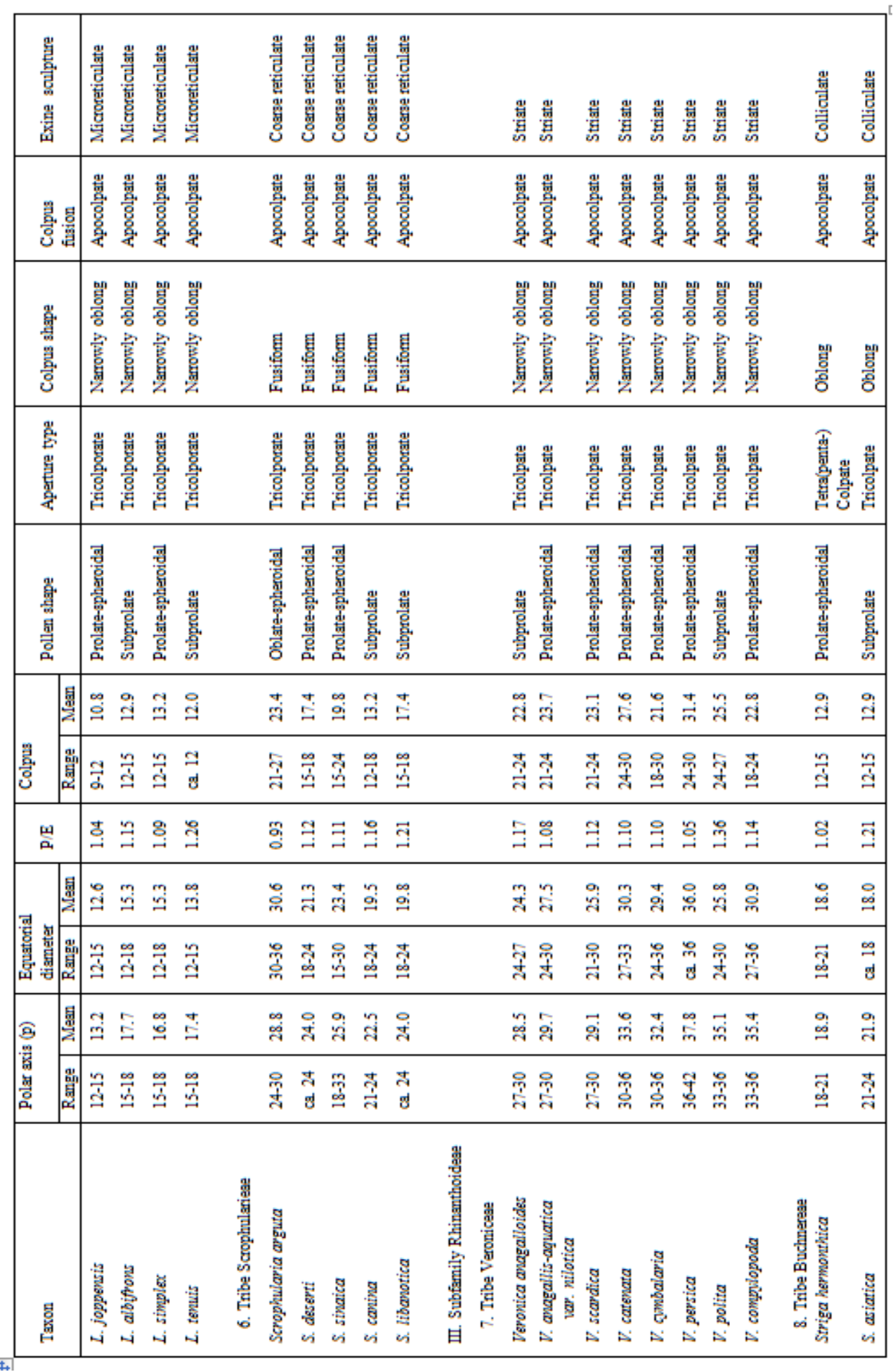




\section{Kickxia type}

Pollens are subprolate, mean polar axis ranges from 14.1-24.3 $\mu \mathrm{m}$. and equatorial diam. 12.0$18.9 \mu \mathrm{m}$, or prolate-spheroidal P. 12.6-16.8 $\mu \mathrm{m}$ and E. 12.3-15.3 $\mu \mathrm{m}$; apocolpate, colpi long, narrow or slightly wide, narrowly oblong with margins that are parallel and rounded at poles; pore rounded with thin membrane as in Linaria and Lindenbergia (Plate IIIB) or a thick one in the form of a bridge, formed by the extension of the lateral margins of the colpus as in Lindernia and Kickxia (Plate IIIC), lolongate rarely circular. Exine sculpture micro-reticulate.

Representative species: Lindenbergia indica, Lindernia parviflora, Kickxia elatine, K. floribunda, K. aegyptiaca, K. acerbiana, K. nubica, K. macilenta, K. gracilis, K. pseudoscoparia, K. hastata, Linaria haelava, L. joppensis, L. albifrons, L. simplex and L. tenuis.

Table (3): Distribution of the pollen types, with special reference to the number among the genera and their related species.

\begin{tabular}{|c|c|c|c|c|}
\hline \multicolumn{4}{|c|}{ Taxon } & \multirow[b]{2}{*}{ Pollen type } \\
\hline Subfamily & Tribe & Genus & $\begin{array}{l}\text { No. of } \\
\text { species }\end{array}$ & \\
\hline Verbascoideae & $\begin{array}{l}\text { Verbasceae } \\
\text { Aptosimeae }\end{array}$ & $\begin{array}{l}\text { Verbascum } \\
\text { Celsia } \\
\text { Anticharis }\end{array}$ & $\begin{array}{l}6 \\
1 \\
3\end{array}$ & $\begin{array}{l}\text { Scrophularia } \\
\text { Scrophularia } \\
\text { Anticharis } \\
\end{array}$ \\
\hline Scrophularoideae & $\begin{array}{l}\text { Gratioleae } \\
\text { Manuleae } \\
\text { Antirrhineae } \\
\text { Scrophularieae }\end{array}$ & $\begin{array}{l}\text { Lindenbergia } \\
\text { Lindernia } \\
\text { Peplidium } \\
\text { Bacopa } \\
\text { Limosella } \\
\text { Jamesbrittania } \\
\text { Kickxia } \\
\text { Linaria } \\
\text { Anarrhinum } \\
\text { Misopates } \\
\text { Scrophularia }\end{array}$ & $\begin{array}{l}1 \\
1 \\
1 \\
1 \\
1 \\
1 \\
9 \\
5 \\
1 \\
1 \\
5\end{array}$ & $\begin{array}{l}\text { Kickxia } \\
\text { Kickxia } \\
\text { Peplidium } \\
\text { Bacopa } \\
\text { Bacopa } \\
\text { Bacopa } \\
\text { Kickxia } \\
\text { Kickxia } \\
\text { Scrophularia } \\
\text { Scrophularia } \\
\text { Scrophularia } \\
\end{array}$ \\
\hline Rhinanthoideae & $\begin{array}{l}\text { Veroniceae } \\
\text { Buchnerae }\end{array}$ & $\begin{array}{l}\text { Veronica } \\
\text { Striga }\end{array}$ & $\begin{array}{l}8 \\
2 \\
\end{array}$ & $\begin{array}{l}\text { Veronica } \\
\text { Striga }\end{array}$ \\
\hline
\end{tabular}

\section{Scrophularia type}

Pollen grains vary from prolate-spheroidal to oblate-spheroidal or subprolate; apocolpate, colpi long, wide, fusiform with the widest part near equator and tapering at poles; membrane thick and smooth, pores operculate, lolongate except in spp. of Verbascum \& Celsia where it is circular. Exine sculpture coarse reticulate or micro-reticulate (Plate IVA-D).

Representative species: Anarrhinum forskaohlii, Misopates orontium, Celsia parviflora, Scrophularia arguta, S. deserti, S. sinaica, S. canina, S. libanotica, Verbascum sinaiticum, $V$. sinuatum, $V$. eremobium, var. subsinguliflorm, $V$. letourneuxii and $V$. schimperianum.

The characters used to delimit the seven pollen morphotypes are relatively widely variable and are reliable for comparative purposes. 
Pollen Atlas of the flora of Egypt. 5. Species of Scrophulariaceae

Table (3) gives the distribution of the pollen types among the investigated taxa, which can be followed through the numbers of the representative taxa.

It will be noticed that Kickxia, Scrophularia and Veronica pollen types are represented by 16,14 and 8 species respectively. The greatest diversity is exhibited in Scrophularia pollen type with Verbascum and Celsia belonging to Verbascoideae; as well as Anarrhinum and Misopates; and Scrophularia of Scrophularoideae. Although represented by a higher number of 16 species, Kickxia pollen type is only represented by taxa belonging to Scrophularoideae viz. Lindenbergia, and Lindernia of Gratioleae, as well as Kickxia and Linaria of Antirrhineae. The Veronica pollen type is only known among the Veronica species, tribe Veroniceae of Rhinanthoideae.

The other four pollen types are represented by 1-3 species each. Anticharis (tribe Aptosimeae) is characterized by the Anticharis pollen type which is characterized by pollen tetrads and syncolporate apertures (Plate IA,B\&C). According to Verghese (1968), Anticharis is the only genus of tribe Aptosimeae that appears to be unique in the family in having tetrad pollen grains, which is considered as an advanced character in the family.

Jamesbrittania (tribe Manuleae), share Bacopa and Limosella (tribe Gratioleae) in its pollen characters and are assigned to the Bacopa pollen type (including Verbascum fruticulosum, Plate ID). The number of aperture and exine sculpture distinguish between Veronica and Striga pollen types. The Veronica pollen type is characterized by tricolpate grains with striate exine sculpture (Plate IIC\&D); the Striga pollen type is characterized by tetra or penta colpate grains and colliculate exine sculpture (Plate IIA\&B).
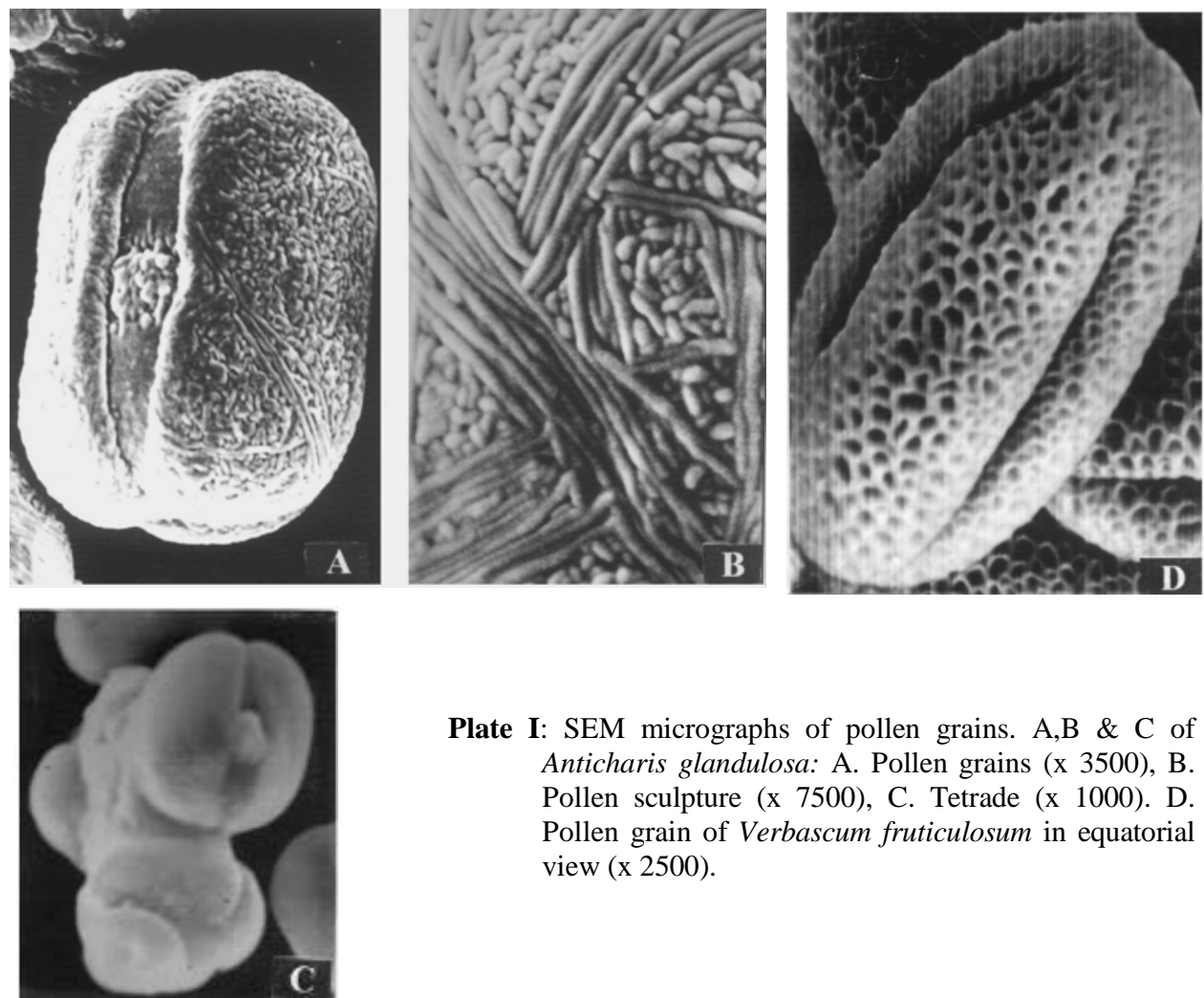

Plate I: SEM micrographs of pollen grains. A,B \& C of Anticharis glandulosa: A. Pollen grains (x 3500), B. Pollen sculpture (x 7500), C. Tetrade (x 1000). D. Pollen grain of Verbascum fruticulosum in equatorial view (x 2500). 

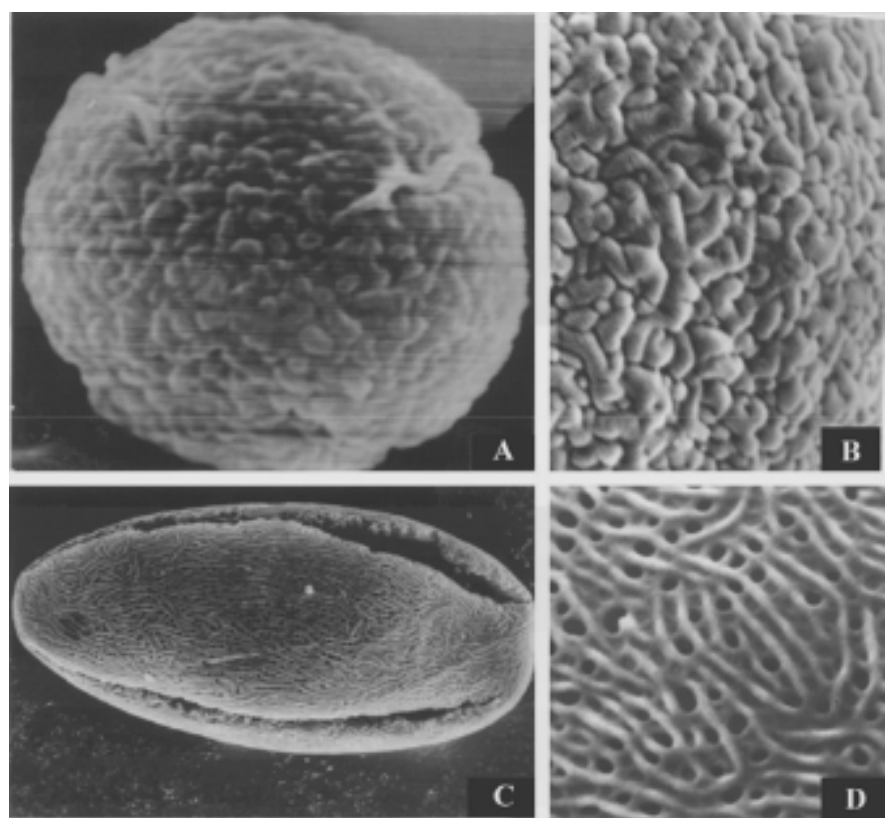

Plate II: SEM micrographs of pollen grains: A \& B of Striga hermonthica: A. Polar view (x 2500), B. Pollen sculpture (x 7500). C \& D Pollen grain of Veronica anagalloides: C. Equatorial view (x 2500), D. Pollen sculpture (x 7500).
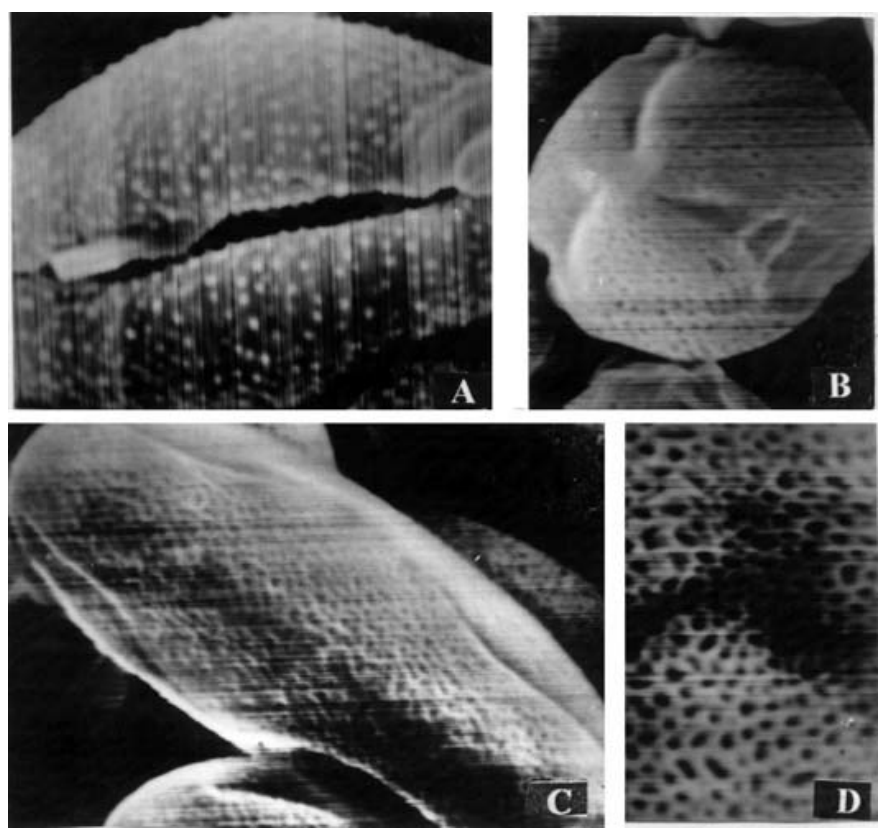
Plate III: SEM micrographs of pollen grains: A of Peplidium humifusum in equatorial view (x 2500). B. of Lindenbergia indica in polar view (x 2500), C \& D. of Kickxia aegyptiaca: C. Equatorial view (x 2500), D. Pollen sculpture (x 7500).
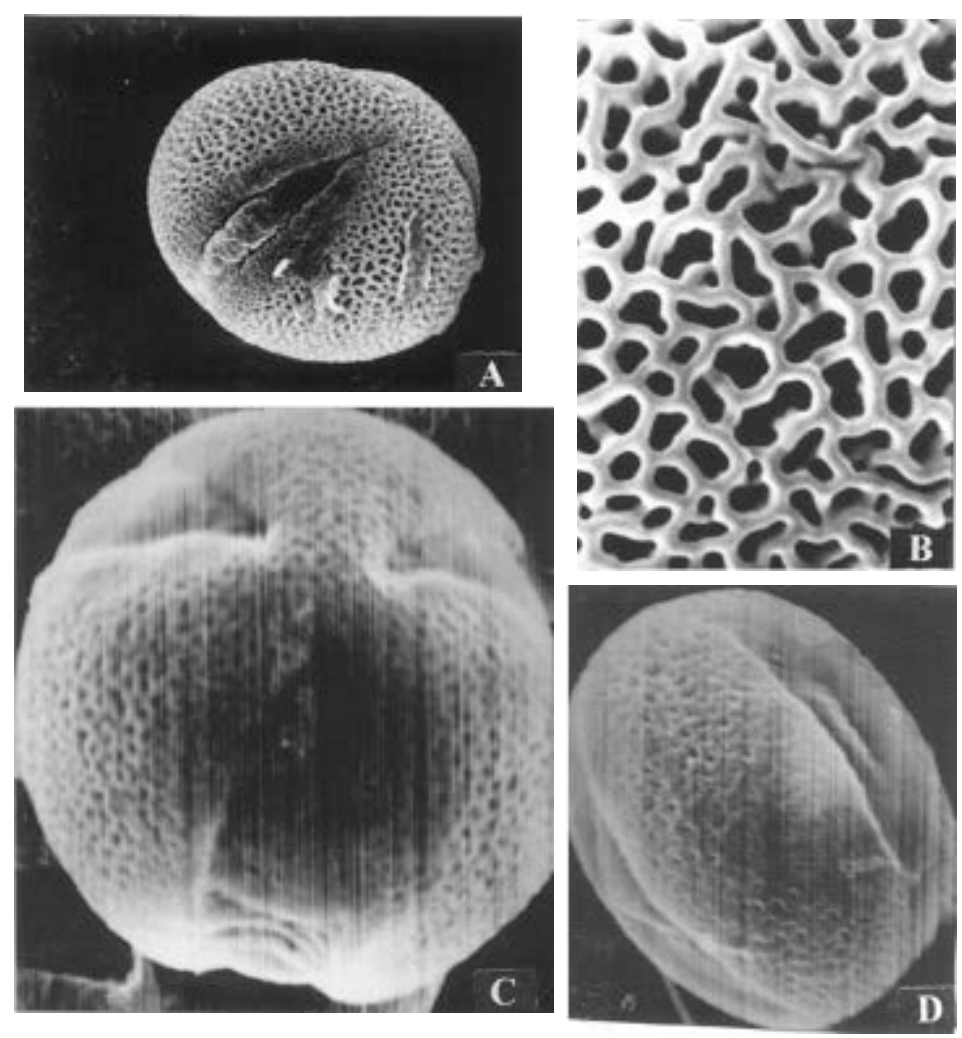

Plate IV: SEM micrographs of pollen grains: A \& B of Scrophularia arguta: A. Equatorial view (x 2500), B. Pollen sculpture (x 7500). C. of Verbascum eremobium in polar view (x 2500). D. of Misopates orontium in equatorial view (x 2500).

\section{Acknowledgments}

The authors wish to acknowledge Prof. Dr. M. N. El-Hadidi, Cairo University, who kindly read the manuscript and gave useful comment.

\section{References}

Argue, C. L. 1980. Pollen morphology in the genus Mimulus (Scrophula-riaceae) and its taxonomic significance. Amer. J. Bot. 67(1): 68-87.

1990. Pllen morphology of Deinostema, Geochorda, Gratiola, Ildefonsia, Sophronanthe and Trigiola (Scrophulariaceae, Gratioleae, Gratiolinae). Cand. J. Bot. 68: 1651-1660.

1993. Pollen morphology in the Selagineae, Manuleae (Scrophulariaceae), and selected Globulariaceae and its taxonomic significance. Amer. J. Bo. 80(6): 723-733. 
Bolliger, M. \& Wick, L. 1990. The pollen morphology of Odontites (Scrophulariaceae) and its Taxonomic significance. Plant systematics \& Evolution. 173: 159-178.

El-Hadidi, M. N., Hosny, A. I., El-Husseini, N. \& Shamso, E. 1999. Scrophulariaceae in the flora of Egypt. 1. Systematic revision of the indigenous taxa. Taeckholmia 19(2): 227-259.

Elisens, W. J. 1985c. The systematic relationship of Asarina procumbens to New World species in tribe Antirrhineae (Scrophulariaceae). Madrono. 32: 168-178.

1986. Pollen morphology and Systematic relationships among New World species in tribe Antirrhineae (Scrophulariaceae). Amer. J. Bot. 73(9): 1298-1311.

Erdtman, G. 1952. Pollen morphology and Plant taxonomy: Angiosperms. Almqvist \& Wiksell, Stockholm.

Erdtman, G. 1960. The acetolysis method- a revised description. Svensk. Bot Tidskr. 54: 561-564.

Ikuse, M. 1956. Pollen grains of Japan. Hirokawa Publ., Tokyo.

Natarajan, A. T. 1957. Studies in the morphology of pollen grains - Tubiflorae. Phyton. 8: 21-42.

Olsson, U. 1974. A biometric study of the pollen morphology of Linaria vulgaris (L.) Miller and L. repens (L.) Miller (Scrophulariaceae) and their hybrid progeny in F-1 and F-2 generations. Grana Palynol. 14: 92-99.

Praglowski, J. \& Punt, W. 1973. An elucidation of the microreticulate structure of the exine. Grana Palynol. 13: 45-50.

Praglowski, J. \& Raj, B. 1979. On some pollen morphological concepts. Grana Palynol. 18: 109-113.

Risch, G. 1939. Die pollenkorner der in Deutschland wild wachsend on Scrophulariaceen. Ber. Deut. Bot. Ges. 57: 108-121.

Verghese, T. M. 1968. Studies in the family Scrophulariaceae. II: Pollen morphology. J. Palynol. 4: 91-97.

Wodehous, R. P. 1936. Pollen grains. New York. 